\title{
LA EVOLUCIÓN DE LA JUSTICIA CONSTITUCIONAL EN BOLIVIA. APUNTES SOBRE EL MODELO DE CONTROL CONCENTRADO Y PLURAL DE CONSTITUCIONALIDAD
}

\section{The Evolution of Constitutional Justice in Bolivia. Notes on the Model of Plural and Concentrated Control of Constitutionality}

\author{
ALAN E. VARGAS LIMA' \\ Universidad Franz Tamayo \\ alanvargas84@hotmail.com \\ Cómo citar/Citation \\ Vargas Lima, A. E. (2016). \\ La evolución de la justicia constitucional en Bolivia. \\ Apuntes sobre el modelo de control concentrado y plural de constitucionalidad. \\ Anuario Iberoamericano de Justicia Constitucional, 20, 369-404 \\ doi: http://dx.doi.org/10.18042/cepc/aijc.20.13
}

\section{Resumen}

Para desarrollar la fundamentación doctrinal del tema propuesto, se hará una breve referencia a la evolución histórica del control de constitucionalidad en Bolivia,

Especialista en derecho constitucional y procedimientos constitucionales. Docente de la Universidad Privada Franz Tamayo, del Centro de Capacitación Municipal y de la Universidad Salesiana de Bolivia. Autor de distintos libros sobre derecho constitucional, derecho procesal constitucional y derechos humanos. Miembro de la Academia Boliviana de Estudios Constitucionales, del Instituto Iberoamericano de Derecho Procesal Constitucional, Sección Nacional (Bolivia), y secretario académico de la Asociación Boliviana de Derecho Procesal Constitucional. Abogado de la Dirección de Asesoría Legal del Gobierno Autónomo Municipal de La Paz. Responsable del blog jurídico Tren Fugitivo Boliviano. 
así como los principales antecedentes de la creación del Tribunal Constitucional en el país, para luego examinar la configuración actual del sistema de control de constitucionalidad a partir de la Constitución aprobada el año 2009, hasta su más reciente manifestación jurisprudencial, como control de carácter concentrado y de naturaleza plural, distinta de otras formas de control existentes en el Derecho Comparado.

\section{Palabras clave}

Control normativo; control competencial; control tutelar; control plural de constitucionalidad; Tribunal Constitucional Plurinacional.

\section{Abstract}

To develop the doctrinal basis of the proposed topic, a brief reference to the historical evolution of the control of constitutionality in Bolivia, as well as the main background of the creation of the Constitutional Court in the country, will be to then examine the year 2009, the current configuration of the system's constitutionality from the approved Constitution until its most recent jurisprudential manifestation, as control of concentrated character and nature plural, distinct from other forms of control existing in comparative law.

\section{Keywords}

Regulatory control; control competence; control protect; plural control of constitutionality; Plurinational Constitutional Court. 


\section{SUMARIO}

I. EL CONTROL DE CONSTITUCIONALIDAD EN BOLIVIA: 1. Antecedentes del control de constitucionalidad en la historia republicana; 2. Antecedentes de la creación del Tribunal Constitucional en Bolivia; 3. La configuración constitucional del sistema de control de constitucionalidad en Bolivia. II. EL RECIENTE DESARROLLO TEÓRICO Y JURISPRUDENCIAL SOBRE EL SISTEMA DE CONTROL PLURAL DE CONSTITUCIONALIDAD EN BOLIVIA: 1. Estructura del modelo plural de control de constitucionalidad; 2. Configuración normativa del órgano de control; 3 . Las dimensiones del control de constitucionalidad en Bolivia: 3.1. Control normativo de constitucionalidad de las disposiciones legales; 3.2. Control competencial de constitucionalidad; 3.3. Control tutelar sobre la vigencia de los derechos fundamentales. III. DESARROLLO JURISPRUDENCIAL DEL MODELO PLURAL DE CONTROL CONSTITUCIONAL. IV. CONCLUSIONES. V. BIBLIOGRAFÍA.

\section{EL CONTROL DE CONSTITUCIONALIDAD EN BOLIVIA²}

Una breve revisión de las reformas y modificaciones del sistema constitucional de nuestro país, en cuanto se refiere al sistema de control de constitucionalidad, permite afirmar que el Estado boliviano en su desarrollo histórico-legislativo adoptó los diferentes modelos que se conocen en la doctrina del derecho procesal constitucional. Así en un primer momento de su vida republicana (1826-1861), bajo la influencia del liberalismo francés, configuró un modelo politico de control de constitucionalidad a través de un Consejo de Estado; en una

2 El presente trabajo fue presentado en las Jornadas Sudamericanas de Derecho Constitucional, evento organizado por la Asociación Chilena de Derecho Constitucional, y que se realizó los días 5 y 6 de mayo de 2016, en la Facultad de Derecho de la Pontificia Universidad Católica de Chile. También fue expuesto en el III Congreso Boliviano de Derecho Constitucional y Primeras Jornadas Nacionales de Derecho Procesal Constitucional «Homenaje al Dr. Pablo Dermizaky Peredo», evento organizado por la Academia Boliviana de Estudios Constitucionales (ABEC), y que se realizó los días 28 al 30 de julio de 2016, en la ciudad de Cochabamba (Bolivia). 
segunda etapa (1861-1994), adoptó el modelo americano, es decir, el sistema jurisdiccional difuso de control de constitucionalidad a través de la Corte Suprema de Justicia; en la tercera etapa (1994-2009), adoptó el sistema jurisdiccional concentrado de control de constitucionalidad con la atribución exclusiva del control a un órgano especializado proveniente del modelo europeo, que fue denominado Tribunal Constitucional ${ }^{3}$ y, finalmente, en la cuarta etapa (2009 hacia adelante), se ha configurado constitucionalmente un sistema predominantemente concentrado y plural de constitucionalidad en Bolivia, según lo ha precisado la propia jurisprudencia del Tribunal Constitucional Plurinacional.

\section{ANTECEDENTES DEL CONTROL DE CONSTITUCIONALIDAD EN LA HISTORIA REPUBLICANA}

Cabe señalar que inicialmente se estableció un sistema de control de constitucionalidad parecido al modelo francés, encomendando dicha labor al propio Poder Legislativo. En efecto, la Constitución bolivariana de 1826, en su art. 51, al nombrar las atribuciones de la Cámara de Censores (que según Bolívar era el Poder Moral del Estado), estableció textualmente lo siguiente: «10 Velar si el Gobierno cumple y hace cumplir la Constitución, las leyes y los tratados públicos; $2^{\circ}$ Acusar ante el Senado las infracciones que el Ejecutivo haga de la Constitución, las leyes y los tratados públicos», lo que implica el ejercicio de un control político de constitucionalidad, entendiendo que existe un mecanismo de control político, cuando se atribuye la defensa de la

3 Un breve análisis exhaustivo sobre las bases doctrinales y las experiencias de los sistemas de control de constitucionalidad predominantes en el mundo, así como los antecedentes del control jurisdiccional en el caso boliviano, con especial énfasis sobre los alcances, implicaciones, y consecuencias del modelo de control político, así como del modelo de control jurisdiccional de constitucionalidad, y su evolución en Bolivia desde 1826 hasta 1967 puede verse en Galindo De Ugarte (1994). Por otro lado, los antecedentes del debate nacional sobre la creación del Tribunal Constitucional en Bolivia, así como las tesis favorables y contrarias acerca de su implementación en nuestro país, se encuentran ampliamente detalladas en el trabajo de Galindo Decker (1994). Asimismo, para constatar la evolución del control de constitucionalidad en nuestro país de acuerdo a su configuración constitucional, es de utilidad consultar el ensayo de Rivera Santivañez (1999: 45-86). Respecto a la evolución normativa, doctrinal y jurisprudencial que ha tenido el modelo americano de control jurisdiccional difuso en nuestro país, es muy útil consultar el trabajo de Urcullo Reyes (2003: 65-99). Finalmente, cabe considerar que un estudio sobre el sistema de control de constitucionalidad vigente en bolivia, ha sido ampliamente analizado y expuesto por el exmagistrado decano del Tribunal Constitucional Durán Ribera (2003: 187-202). 
Constitución a órganos de carácter electivo popular, como el Legislativo, una de sus cámaras, el Ejecutivo u otro órgano (Asbun, 1999: 6). En este sentido, cabe recordar que la "Constitución bolivariana» de 1826 (denominada así en homenaje al autor del proyecto de dicha Constitución: el Libertador Simón Bolívar), conocida también como "Constitución vitalicia» (dado que establecía un presidente y una Cámara de Censores, ambos de duración vitalicia), preveía que el poder político del Estado se ejercía a través del Poder Electoral, Poder Legislativo, Poder Ejecutivo y Poder Judicial.

No obstante, en sentido contrario se pronuncia el autor alemán Norbert Lösing, quien en su análisis comparativo sobre la jurisdicción constitucional en Latinoamérica, y a tiempo de describir el control constitucional en los inicios del constitucionalismo boliviano, señala que el Poder Legislativo estaba conformado por tres cámaras, entre ellas la mencionada Cámara de Censores, a la cual le correspondía realizar el control de constitucionalidad de los actos del Ejecutivo; en consecuencia, y según el criterio de este autor, «el control constitucional de las leyes no estaba previsto. Ni mucho menos un recurso para que los ciudadanos individualmente, pudieran defenderse frente a las violaciones de la Constitución. Con la Ley del 8 de junio de 1827 se expidió la reglamentación de la organización judicial. Siguiendo los preceptos de la Constitución, no se le atribuyó a la justicia función de control alguna. En mayo de 1829 el mariscal de campo Andrés de Santa Cruz, tomó el poder y gobernó en principio prescindiendo del órgano legislativo hasta que fue expedida la nueva Constitución de 1831» (Lösing, 2002: 240).

Sin embargo, el autor español Francisco Fernández Segado, realizando un análisis objetivo de los antecedentes del control de constitucionalidad en Bolivia, ha llegado a afirmar que ciertamente, en el Mensaje al Congreso Constituyente de Bolivia (Bolívar, 1973: 99-112), el Libertador Simón Bolívar hizo una observación en torno a la necesidad de instaurar un sistema de control de la constitucionalidad de los actos del poder público, razón por la cual pensó en un órgano político encaminado a velar por la salvaguarda de la Constitución, y ese órgano fue la tercera cámara del Poder Legislativo: la Cámara de Censores (cámara que se situaba junto a la Cámara de Tribunos y a la Cámara de Senadores); a cuyo efecto, estableció que «serán ellos (los censores) los fiscales contra el Gobierno para celar si la Constitución y los tratados públicos se observan con religión». Entonces, «el modelo político de control de la constitucionalidad esbozado en Francia, estaba en buena medida presente en el pensamiento bolivariano y de él pasaría a la Constitución de 1826» (Fernández Segado, 2002: 11).

De ahí que la Constitución Política del Estado de 1826, haciendo plenamente suya la idea bolivariana, acogía un Poder Legislativo tricameral, una de cuyas cámaras, la Cámara de Censores, asumía la facultad de velar si el Gobierno cumple y hace cumplir la Constitución, las leyes y los tratados pú- 
blicos, debiendo acusar ante el Senado las infracciones que el Ejecutivo hiciera tanto de la Constitución, como de las leyes y los tratados públicos: «En definitiva, en esta primera etapa del constitucionalismo boliviano, que se prolonga hasta la Constitución de 21 de septiembre de 1851, que sentará las bases para un cambio de orientación, el control político de constitucionalidad, con una u otra característica, aparece profundamente arraigado, situación que bien puede considerarse como paradigmática, pues ciertamente, con notables alteraciones cronológicas en ocasiones, se repite en muchos otros países» (Fernández Segado, 2012: 424).

Posteriormente, en la reforma constitucional del año 1831 se creó el Consejo de Estado otorgándole, entre otras, la atribución de ejercer el control de constitucionalidad. Por disposición del art. 93 de la Constitución, dicho organismo estuvo «compuesto de siete individuos, nombrados por el Congreso a pluralidad absoluta de votos», a ellos se sumaban el presidente y vicepresidente de la República, una vez fenecido su mandato. Una de las atribuciones del Consejo de Estado fue la de «velar sobre la observancia de la Constitución e informar documentadamente al Cuerpo Legislativo sobre las infracciones de ella». Esa tarea, ciertamente constituye una modalidad de control de constitucionalidad (supeditada al Poder Legislativo), que se mantuvo en la reforma constitucional de 1834 .

Mediante la reforma constitucional del año 1839 se suprimió el Consejo de Estado sin que se asigne la tarea del control de constitucionalidad a un órgano específico. Sin embargo, de acuerdo al art. 77 de la misma Constitución, entre las atribuciones del Poder Ejecutivo se preveía: «2 Velar en la exacta observancia de la Constitución y hacer que todos los funcionarios públicos desempeñen cumplidamente sus deberes» (Trigo, 2003: 293); lo que pareciera mostrar que se pretendió concentrar la labor del control de constitucionalidad en un órgano de naturaleza política, como es el Poder Ejecutivo.

El año 1843, al reformar la Constitución, se restableció el organismo bajo el nombre de Consejo Nacional con una composición muy diferenciada; y el texto constitucional le otorgó la facultad de velar sobre la observancia de la Constitución. En 1851 se volvió a reformar la Constitución y, en lo que respecta al tema de control de constitucionalidad, se suprimió nuevamente el Consejo Nacional y no se previó un mecanismo ni institución para desarrollar las labores del órgano depuesto ${ }^{4}$. Sin embargo, es importante precisar que el

4 De manera concordante con este criterio, Norbert Lösing señala que en la Constitución de 1851 no se preveía ningún tipo de control constitucional, ni ejecutivo, legislativo o judicial; sin embargo, el art. 82 de la Constitución de 1851 reconocía por primera vez la supremacía de la Constitución frente a las leyes ordinarias. «No obstante, no se infirió de esa regla una competencia para el control constitucional por vía 
art. 82 de esa Constitución, a tiempo de proclamar que el Poder Judicial residía en la Corte Suprema, en las Cortes Superiores y Juzgados de la República, establecía que «a ellos pertenece privativamente la potestad de juzgar y aplicar esta Constitución con preferencia a las demás leyes, y las leyes con preferencia a otras resoluciones», estableciendo así la regla de aplicación preferente de la Constitución frente a cualquier otra norma del ordenamiento jurídico5.

A través de la reforma de la Constitución realizada el año 1861, se restituyó el Consejo de Estado, y en aquella ocasión se ampliaron sus atribuciones en lo que concierne a la labor de control de constitucionalidad. Así, por ejemplo, en el ámbito consultivo y correctivo, el art. 41 estableció que:

Son atribuciones del Consejo de Estado: 3) Dar su voto sobre los proyectos de ley o reglamento, que el Gobierno le pase por vía de consulta. 4) Juzgar a los magistrados de la Corte Suprema y a los vocales del Tribunal General de Valores, cuando la Asamblea declare haber lugar a la acusación. 7) Declarar la legalidad o ilegalidad de los impuestos y establecimientos creados por las municipalidades. 9) Recibir durante el receso de la Asamblea, las denuncias y querellas interpuestas contra el Presidente de la República y Ministros del despacho, por actos inconstitucionales, para someterlas a la Asamblea, previa instrucción conveniente.

Resulta importante señalar que en la reforma constitucional del año 1861, paralelamente a la creación del Consejo de Estado, se adoptó el modelo de control de constitucionalidad conocido como control jurisdiccional difuso o modelo americano; toda vez que la Constitución reformada consagró, por una parte, el principio de la supremacía constitucional cuando en su art. 86 estableció textualmente lo siguiente: «Las autoridades y tribunales aplicarán esta Constitución con preferencia a las leyes, y estas con preferencia a cualesquiera otras resoluciones»y, por otra parte, encomendó la labor de control de constitucionalidad, por la vía de acción concreta, al Tribunal Supremo de Justicia, cuando en su art. 65 dispuso que «son atribuciones de la Corte de

judicial. Hasta ese momento no se conocieron en Bolivia los mecanismos procesales para garantizar la efectividad de los derechos fundamentales» (Lösing, 2002: 241).

5 «Tanto el art. 82 de la Constitución de 1851, como el párrafo 20 del art. 228 de la Constitución de 1967, contienen un compulsivo mandato que magistrados y jueces no pueden ni deben olvidarlo porque él constituye una de las más preciadas garantías del ordenamiento jurídico de la Nación». Asimismo, cabe tener presente que: «La facultad o atribución del Supremo Tribunal para conocer de este proceso solemne y quizá el más importante y valioso, cual es el proceso de constitucionalidad o inconstitucionalidad de las leyes, decretos y resoluciones, aparece por primera vez en la Constitución de 1861»(Virreira Flor, 1977: 87). 
Casación (Tribunal Supremo de Justicia), además de las que señalan las leyes: $2^{\circ}$ Conocer de los negocios de puro derecho, cuya decisión depende de la constitucionalidad o inconstitucionalidad de las leyes» (Trigo, 2003: 358).

Posteriormente, en la reforma constitucional realizada el año 1868 se suprimió el Consejo de Estado, manteniéndose invariable la atribución de la Corte de Casación (Tribunal Supremo de Justicia) de conocer de los negocios de puro derecho, cuya decisión depende de la constitucionalidad de las leyes; empero, en la reforma del año 1871 se restableció nuevamente con modificaciones en su composición y atribuciones, conforme a las cuales se le otorgó la atribución de ejercer el control de constitucionalidad en el orden normativo preventivo y correctivo.

Entonces, sobre la base de la norma constitucional incorporada en 1861, y que se mantuvo inalterable en 1868, se organizó el control jurisdiccional de constitucionalidad ejercido por todos los jueces y tribunales del país, que al resolver un caso concreto, tenían la atribución y obligación de inaplicar una disposición claramente incompatible con las normas de la Constitución; asimismo, el control era ejercido por la Corte Suprema de Justicia, la que tenía la facultad y atribución de conocer y tramitar el recurso de inaplicabilidad por inconstitucionalidad de una disposición legal, cuya decisión sólo tenía un efecto inter partes, es decir, para el caso concreto ${ }^{6}$.

Sin embargo, y de acuerdo al criterio del exmagistrado del Tribunal Constitucional de Bolivia, José Antonio Rivera Santiváñez, ese modelo de control «difuso» de constitucionalidad no rindió sus frutos esperados, debido a diversas razones, entre las que se pueden señalar las siguientes (Rivera Santiváñez, 2008: 46): a) la no vigencia permanente del régimen democrático de Gobierno y del Estado de Derecho, que a lo largo de la historia republicana tuvo una presencia fugaz, debido a las permanentes interrupciones mediante los golpes de Estado que instauraron regímenes de hecho o de facto; b) la falta de una doctrina constitucional boliviana sólida y carencia de una cultura constitucional, pues habrá de recordar que por la falta de una vigencia ma-

6 «El nuevo Código de Procedimiento Civil, dice pues, que el proceso de inconstitucionalidad procede en todos los casos en que una persona individual o colectiva (natural o jurídica) 'se creyere agraviada por los efectos de una ley, decreto o cualquier género de resolución', pudiendo interponer la respectiva demanda ante el Supremo Tribunal pidiendo 'se declare la inaplicabilidad' de la ley, del decreto o de la resolución, en todo o en parte, en el caso concreto en que el demandante se cree agraviado. Se pide la declaración de 'inaplicabilidad' de la ley, decreto o resolución, por 'inconstitucional', porque el Poder Judicial no puede declarar llanamente la inconstitucionalidad, ya que no es 'censor directo de los Poderes Legislativo y Ejecutivo'. Y, esa declaración deberá recaer sobre el punto concreto demandado [...]» (Virreira Flor, 1977: 93). 
terial de la Constitución el derecho constitucional fue objeto de un estudio enciclopédico más que práctico y concreto, además que el sistema constitucional boliviano se configuró sobre la base del constitucionalismo clásico, por lo tanto, sobre la base del principio de legalidad y no tanto del principio de supremacía constitucional, lo que dio lugar a que se catalogara la Constitución como una mera carta política y no una norma jurídica, cuando menos eso sucedió en el siglo xx y las primeras ocho décadas del siglo xx; c) la incompleta positivación de los derechos humanos y la falta de judicialización de los mismos, pues habrá de recordar que en esa materia la Constitución no fue generosa, ya que recién en 1931 se introdujo el habeas corpus como garantía para el derecho a la libertad física, y el amparo constitucional en 1967, y ello incidió significativamente en la poca ineficacia del sistema en el control tutelar de constitucionalidad; y d) extremada concentración de funciones en la Corte Suprema de Justicia, como la función jurisdiccional ordinaria y contenciosa, la jurisdicción constitucional y la labor administrativa y disciplinaria, que incidió en la generación de la retardación de justicia y que el control de constitucionalidad no tuviese la eficacia esperada.

De ahí que, en criterio de Rivera Santiváñez, haciendo una evaluación objetiva del control de constitucionalidad en la etapa anterior a la creación del Tribunal Constitucional, se puede concluir que no fue eficiente ni logró los resultados esperados, pues no existió un desarrollo doctrinal ni jurisprudencial sólido, sino que por el contrario, se caracterizó por la excesiva retardación de justicia (Rivera Santiváñez, 2007).

\section{ANTECEDENTES DE LA CREACIÓN DEL TRIBUNAL CONSTITUCIONAL EN BOLIVIA}

Entre los antecedentes de la implementación del control constitucional en Bolivia a través de un órgano especializado, debemos recordar que en virtud de la Ley 1585 de Reforma a la Constitución Política del Estado, promulgada en fecha 12 de agosto de 1994, se introdujeron diversas modificaciones al texto constitucional que se hallaba vigente sin cambio alguno desde el año 1967 hasta ese entonces, incluyendo la creación por mandato constitucional, de un Tribunal Constitucional en la vida institucional boliviana.

En este sentido, mediante dicha reforma constitucional efectuada en 1994, se reformaron aproximadamente treinta y cinco (35) artículos de la Constitución boliviana. Dichas modificaciones pueden resumirse en lo siguiente:

a) inserción de los pueblos originarios y comunidades indigenas a la estructura social del Estado, a cuyo efecto se definió la estructura social como mul- 
tiétnica y pluricultural, así como de las bases de su organización como son la unión y la solidaridad;

b) modificaciones en el sistema electoral, cambiando el requisito de la edad para el ejercicio de la ciudadanía de 21 años que regía hasta entonces, a 18 años;

c) fortalecimiento del entonces Poder Legislativo, a través de la reforma del sistema de elección de los diputados para devolverles legitimidad y representatividad, con la introducción del sistema del doble voto en circunscripciones uni y plurinominales;

d) estabilidad y gobernabilidad en el ejercicio del Gobierno nacional, reformando las reglas para la elección congresal del presidente y vicepresidente de la República, en aquellos casos en los que ninguno de los candidatos obtenga mayoría absoluta de votos en las elecciones generales;

e) plena vigencia y protección de los derechos humanos ${ }^{7}$ como base del orden democrático constitucional, a cuyo efecto se ha creado la Defensoría del Pueblo con la misión de velar por la vigencia y cumplimiento de los derechos y garantías de las personas con relación al sector público;

f) fortalecimiento de los gobiernos locales autónomos como unidades básicas del desarrollo sostenible sobre la base de la planificación participativa y el control social;

g) seguridad jurídica y fortalecimiento del orden constitucional reformando la estructura del entonces Poder Judicial (actual Órgano Judicial), mediante la creación del Tribunal Constitucional como máximo intérprete jurisdiccional de la Constitución, asignándole la función del control concentrado de constitucionalidad (Rivera Santiváñez, 2002: 5-8).

\footnotetext{
Algunos autores estiman que la expresión, «derechos humanos» o «derechos del hombre», llamados clásicamente «derechos naturales», y actualmente «derechos morales», no son en realidad auténticos derechos protegidos mediante acción procesal ante un juez, sino criterios morales de especial relevancia para la convivencia humana, y que en todo caso, una vez que determinados derechos humanos se positivizan, adquieren la categoría de verdaderos derechos protegidos procesalmente, transformándose en derechos fundamentales vigentes en un determinado ordenamiento jurídico, lo que equivale a decir que los derechos fundamentales son derechos humanos positivados por la legislación interna de un determinado Estado. En otras palabras, lo anterior significa que bajo la expresión «derechos fundamentales», se designa a los derechos garantizados y reconocidos por la Constitución y, en cambio, la denominación «derechos humanos» hace referencia a los derechos proclamados y garantizados por las normas e instrumentos internacionales; los primeros tienen como fuente de producción al legislador constituyente, y los segundos a los Estados y organismos internacionales (Duran Ribera, 2005: 99-100).
} 
A ello se debe agregar que dicha reforma constitucional indudablemente se constituye en un hecho trascendental con una importancia histórica sin precedentes dentro de la evolución del sistema constitucional boliviano, puesto que en aquella oportunidad, y por vez primera en la historia republicana de nuestro país, se reformó la Ley Fundamental dando cumplimiento a los mecanismos y procedimientos especialmente previstos al efecto por la propia Constitución, vale decir, que se aprobó, sancionó y promulgó la Ley de Reforma Constitucional en observancia de las normas previstas por los arts. $230 \mathrm{al}$ 232 del texto constitucional vigente en ésa época.

Ahora bien, revisando los antecedentes de creación de esta institución —y según nos recuerda el exmagistrado René Baldivieso Guzmán—, la idea de crear un Tribunal Constitucional resultó polémica en Bolivia, ya que diferentes instituciones cívicas, políticas, forenses, académicas y otras representativas de la opinión pública, recibieron con algún escepticismo la iniciativa. Inclusive los órganos jerárquicos del entonces Poder Judicial (actual Órgano Judicial) sumaron su disidencia y protesta por la creación del Tribunal Constitucional. Así por ejemplo, en un documento emitido por la Corte Suprema de Justicia en fecha 29 de marzo de 1993, se sostuvo que:

[...] significaría en los hechos, un inaudito atentado contra el régimen de la juridicidad puesto que la Corte Suprema quedaría reducida, en su función específica, a una rutinaria labor de tribunal de casación o para la solución de los recursos de nulidad en los trámites ordinarios, olvidando que la Corte Suprema no es sólo el más alto Tribunal de Justicia de la República, sino el custodio de la moral pública que debe proteger a la sociedad de los abusos del poder, el respeto a la ley y el imperio del Derecho. No deja de llamar la atención en este documento — agrega Baldivieso- que se haga referencia a una rutinaria labor de tribunal de casación, siendo así que esa labor jurisdiccional del más alto tribunal en materia de justicia ordinaria implica, por el contrario, el estudio meditado y responsable de cada caso para sentar una jurisprudencia que no puede ser producto precisamente de la rutina, sino de interpretaciones creativas de la ley. (Baldivieso Guzman, 2006: 29-30).

De ahí que la creación del Tribunal Constitucional en Bolivia no fue fácil, pues tuvo que enfrentar muchos obstáculos como la reacción de oposición cerrada e irracional de la entonces Corte Suprema de Justicia, así como algún sector del foro de abogados, llegando inclusive a considerar como un "golpe de Estado» la propuesta de su creación como organismo independiente de los demás órganos de poder, lo que inevitablemente dio lugar a que su configuración institucional en la Constitución no fuera óptima, y con el tiempo, se constituyó en uno de los factores que debilitó la eficacia de sus actividades (Rivera Santiváñez, 2008: 47-48). 
Sin embargo, la oposición radical de la Corte Suprema y las críticas «doctrinales» opositoras a la creación de un Tribunal Constitucional como un órgano de control constitucional independiente de los demás órganos de poder, nunca tuvieron asidero jurídico válido; es más, el legislador constituyente, a través de la reforma constitucional de 1994, y considerando la importancia de la creación del nuevo órgano de control de constitucionalidad, así como la necesidad de promover la defensa de los derechos humanos en el país, creó el Tribunal Constitucional —que comenzó a ejercer sus funciones jurisdiccionales en el mes de junio de 1999—, incorporándolo como parte constitutiva del entonces denominado Poder Judicial, vale decir, como uno de sus órganos jurisdiccionales especializados, encargado de realizar el control de constitucionalidad, debiendo ejercer dicho control sobre todos los actos, resoluciones y decisiones de los demás órganos de poder, con independencia de cualquier otra autoridad estatal, en su labor jurisdiccional, es decir, colocado fuera del alcance de los poderes públicos cuyos actos controla, estando sometido solamente a la Constitución.

Por otro lado, en cuanto se refiere al modelo de control de constitucionalidad vigente hasta hace una década atrás, cabe hacer notar que, en opinión de algunos autores, el sistema de control de constitucionalidad adoptado por el Estado boliviano en la reforma constitucional efectuada el año 1994 (y que se mantuvo en la reforma del año 2004) no era en esencia un sistema de control concentrado puro, sino por el contrario, un sistema en el que concurren los elementos del modelo americano como también del europeo ${ }^{8}$; sin embargo, interpretando el verdadero alcance de las normas que consagran el sistema de control de constitucionalidad que nació en la citada reforma constitucional de 1994, vale decir que de las competencias que la Constitución le asignaba al reciente Tribunal Constitucional, se extrae con toda claridad que el legislador constituyente le encomendó a este órgano jurisdiccional las

8 En este sentido se ha pronunciado el exmagistrado del Tribunal Constitucional, José Antonio Rivera Santivañez, quien desarrolla su tesis sosteniendo que «por un lado, a través de la referida reforma constitucional (de 1994), se ha creado el Tribunal Constitucional como el órgano encargado del control concentrado de constitucionalidad y máximo intérprete de la Constitución, lo que encuadra el sistema adoptado en el modelo europeo. Pero por otra parte, el Constituyente no modificó el texto del art. 228 de la Constitución reformada, por cuyo mandato los tribunales y jueces, al revolver un caso concreto dentro de un proceso judicial, tienen la obligación de no aplicar las disposiciones legales que sean contradictorias o incompatibles con las normas previstas en la Constitución, lo cual constituye un acto de control de constitucionalidad y se encuadra en el modelo americano del judicial review o revisión judicial» (Rivera Santivañez, 2002: 583-603). 
tres funciones esenciales que el control de constitucionalidad representa: 1) el control normativo de constitucionalidad, 2) el control de los límites del ejercicio del poder político, 3) el control sobre la salvaguarda de los derechos y garantías, debiendo considerarse que la idea que subyace al modelo de control concentrado de constitucionalidad que nació en la reforma de $1994^{9}$, fue confirmada en la ley de desarrollo constitucional, esto es en la Ley 1836 del Tribunal Constitucional, que estuvo vigente hasta antes de la entrada en vigor de la actual Ley 27 del Tribunal Constitucional Plurinacional.

\section{LA CONFIGURACIÓN CONSTITUCIONAL DEL SISTEMA DE CONTROL DE CONSTITUCIONALIDAD EN BOLIVIA}

Cabe tener presente que según la norma prevista por el art. 179, parágrafo III de la Constitución Política del Estado aprobada el año 2009, la justicia constitucional será ejercida por el Tribunal Constitucional Plurinacional, el cual, por mandato del art. 196 del mismo texto constitucional, debe velar por la supremacía de la Constitución, ejerciendo el control de constitucionalidad, y precautelando el respeto y la vigencia de los derechos fundamentales y las garantías constitucionales.

En virtud de lo dispuesto por las referidas normas constitucionales, Rivera Santiváñez indica que es posible inferir que el Constituyente ha decidido mantener el modelo concentrado (europeo kelseniano) de control de constitucionalidad, encomendando dicha labor a un organismo especializado cual

9 Se debe recordar que inicialmente, Jorge Asbun, en su estudio dedicado a analizar la evolución y perspectivas del control constitucional en Bolivia, afirmó de manera inequívoca que: «En Bolivia, la reforma de 1994, incorporó a la Constitución a través de los artículos 116 y siguientes el modelo de control concentrado de constitucionalidad, encargando al Tribunal Constitucional, mediante el art. 119, las siguientes atribuciones: control de constitucionalidad, defensa de los derechos fundamentales, conflictos de competencia interorgánicas y demandas respecto a procedimientos de reforma constitucional» (Asbun, 1999: 149-150). Años más tarde, estas ideas serían confirmadas por autores internacionales estudiosos de la jurisdicción constitucional en Latinoamérica; así por ejemplo, el profesor chileno Humberto Nogueira llegó a afirmar que «en Bolivia existe un sistema de control constitucional centralizado en un único órgano especializado, integrado por letrados, con un ámbito amplio de competencias, que ejerce dicha jurisdicción con plena independencia de todo otro órgano, tanto respecto de normas como de actos inconstitucionales, por vía de acción y de excepción, teniendo sus sentencias efectos de cosa juzgada, sin existencia de recurso ulterior. Existe así en Bolivia un auténtico Tribunal Constitucional». (Nogueira Alcalá, 2006: 129). 
es el Tribunal Constitucional Plurinacional, aunque con algunos resabios del modelo americano de «revisión judicial»; «[...] empero, ha introducido importantes reformas a la estructura institucional del mencionado órgano de control de constitucionalidad, al ámbito de sus funciones y atribuciones, asimismo a la configuración procesal de los procesos constitucionales que debe conocer y resolver; reformas que en el futuro podrían anular el control de constitucionalidad y, en su caso, permitir se instrumentalice la Justicia Constitucional para garantizar el proyecto de ejercicio hegemónico del poder político» (Rivera Santiváñez, 2009: 43).

En efecto, dicho autor sostiene su tesis señalando que en el ámbito del control de constitucionalidad de las normas, el Tribunal Constitucional Plurinacional tiene el monopolio para anular y expulsar del ordenamiento jurídico las disposiciones legales infraconstitucionales que sean incompatibles con la Constitución, por contradecir e infringir sus preceptos; empero, en esa labor participan los jueces y tribunales de la jurisdicción ordinaria, promoviendo la acción de inconstitucionalidad concreta. De otro lado, en el ámbito del control de constitucionalidad sobre el ejercicio del poder político, el Tribunal Constitucional Plurinacional tiene el monopolio de esa función, a través del conocimiento y resolución de las acciones de conflictos de competencia; sin embargo, en el ámbito de control tutelar de los derechos fundamentales, la labor es realizada por los jueces y tribunales de garantías constitucionales en única instancia. En cambio, el Tribunal Constitucional Plurinacional interviene posteriormente, conociendo y resolviendo las acciones tutelares en grado de revisión de oficio.

Asimismo, Rivera Santiváñez señala que uno de los fundamentos para sostener la tesis de que el modelo adoptado por el Estado plurinacional de Bolivia es el europeo kelseniano, con resabios del modelo americano de control de constitucionalidad, lo que equivale a un sistema de control mixto, se encuentra en las normas previstas por el art. 410, parágrafos I y II de la Constitución, por cuyo mandato todas las personas, naturales y jurídicas, así como los órganos públicos, funciones públicas e instituciones, se encuentran sometidos a la Constitución, que es la norma suprema del ordenamiento jurídico boliviano y goza de primacía frente a cualquier otra disposición normativa; entonces, «de las normas glosadas se puede inferir que los jueces y tribunales de la jurisdicción ordinaria, por mandato constitucional, están impelidos a aplicar la Constitución y no la Ley en un caso concreto en el que tengan la certeza absoluta de que esta última es incompatible con la norma constitucional».

Según este autor, se podría afirmar que el modelo adoptado por el Estado plurinacional de Bolivia, no es un modelo puro, sino que mantiene los resabios del modelo americano, conocido clásicamente como el modelo de control jurisdiccional difuso, porque las normas previstas por el art. 410 de 
la Constitución, al proclamar el principio de la supremacía constitucional y el principio de la jerarquía normativa, implícitamente faculta a los jueces y tribunales a inaplicar la ley, decreto o resolución cuyas normas sean contrarias a la Constitución. «Por consiguiente, todo juez o tribunal ordinario, que tenga la seguridad de que la norma legal sobre cuya base deberá dictar su resolución o sentencia, es contraria a la Constitución, tiene la obligación de no aplicar dicha norma por inconstitucional, y sólo en aquellos casos en los que tenga duda y no certeza, o pretenda que la disposición legal sea anulada a través de una sentencia constitucional con efecto erga omnes, deberá promover el recurso indirecto o incidental de inconstitucionalidad» (Rivera Santiváñez, 2011: 130-131).

Esta postura, ciertamente concuerda plenamente con la posición doctrinal expresada por el jurista español Fernández Segado, cuando señala que una opinión doctrinal muy generalizada subraya la existencia de una clara tendencia convergente entre los dos clásicos modelos; vale decir, que actualmente ya no es posible hallar modelos "puros» de control de constitucionalidad adoptados en los países de Iberoamérica, no pudiendo señalarse que en determinado país predomine sólo el modelo difuso o impere únicamente el modelo concentrado de control de constitucionalidad, dado que la tendencia actual en el mundo contemporáneo, respecto al control jurisdiccional de las leyes y su funcionamiento, revela que ambos modelos se hallan en vías de llegar a su progresiva unificación (Fernández Segado, 2004).

No obstante lo anterior, cabe aclarar que la Ley 27 del Tribunal Constitucional Plurinacional (TCP), ciertamente mantiene en su contenido las normas que sustentan el control concentrado de constitucionalidad en Bolivia, de acuerdo a lo siguiente: el art. 109 de la Ley del TCP, establecía que la acción de inconstitucionalidad concreta, "procederá en los procesos judiciales o administrativos cuya decisión dependa de la constitucionalidad o inconstitucionalidad de una Ley, Estatuto Autonómico, Carta Orgánica, Decreto y todo género de Ordenanzas y Resoluciones no judiciales aplicables a aquellos procesos» (norma derogada por el Código Procesal Constitucional, que en su art. 73, numeral 2, contiene similar previsión), debiendo ser promovida la acción de inconstitucionalidad por el juez, tribunal o autoridad administrativa, de oficio o a instancia de parte, de acuerdo a lo previsto por el art. 79 del mencionado Código.

Lo referido anteriormente, determina que ningún juez, tribunal u órgano administrativo está autorizado para inaplicar norma jurídica alguna, dado que en caso de duda sobre la constitucionalidad de una norma del ordenamiento a ser aplicada al caso concreto que ha de resolver, debe promover inmediatamente el incidente de inconstitucionalidad ante el Tribunal Constitucional Plurinacional, y este entendimiento interpretativo concuerda plenamente con 
lo establecido en el art. 5 de la misma Ley del TCP, cuando establece que «se presume la constitucionalidad de toda ley, decreto, resolución y actos de los Órganos del Estado en todos sus niveles, hasta tanto el Tribunal Constitucional Plurinacional resuelva y declare su inconstitucionalidad». Como se puede ver, la norma de desarrollo constitucional reconoce que el Tribunal Constitucional Plurinacional, en su calidad de máximo guardián y supremo intérprete de la Constitución, es el único órgano autorizado para inaplicar normas o dejar sin efecto los actos de los órganos del Estado cuando estos se hallaren en abierta contradicción con los principios y valores constitucionales, todo lo cual es plenamente incompatible con un sistema de control «difuso».

A lo indicado, debe agregarse que la misma Constitución boliviana aprobada el año 2009, consagra como atribución del Tribunal Constitucional, absolver «las consultas de la Presidenta o del Presidente de la República, de la Asamblea Legislativa Plurinacional, del Tribunal Supremo de Justicia o del Tribunal Agroambiental sobre la constitucionalidad de proyectos de ley», en cuyo caso la decisión del Tribunal Constitucional es de cumplimiento obligatorio. A su vez, tiene la atribución de absolver inclusive «las consultas de las autoridades indígenas originario campesinas sobre la aplicación de sus normas jurídicas aplicables a un caso concreto", y en consecuencia, la decisión del Tribunal Constitucional es obligatoria, lo que corrobora el entendimiento interpretativo expuesto, de que la misma Constitución como Ley Fundamental de nuestro ordenamiento jurídico, encomienda el control de constitucionalidad de manera exclusiva al nuevo Tribunal Constitucional Plurinacional (Duran Ribera, 2003: 187-202).

\section{EL RECIENTE DESARROLLO TEÓRICO Y JURISPRUDENCIAL SOBRE EL SISTEMA DE CONTROL PLURAL DE CONSTITUCIONALIDAD EN BOLIVIA}

Para verificar la transformación que se está produciendo en el sistema de control de constitucionalidad boliviano, cabe señalar que como consecuencia de la aprobación de la Constitución Política del Estado en el año 2009, se ha refundado el Estado boliviano, al abrigo de un modelo constitucional basado en el pluralismo, la interculturalidad y la descolonización, marcando así la era de la "generación del constitucionalismo boliviano", con rasgos y particularidades específicas que lo caracterizan y diferencian de los demás modelos constitucionales, especialmente de aquellos con raíces en el constitucionalismo europeo.

Es así que se ha llegado a configurar un sistema plural de control de constitucionalidad, con bases notorias en el sistema jurisdiccional concentrado de 
control constitucional, que estuvo vigente hasta antes de la aprobación del nuevo texto constitucional; empero, esta vez, se agrega un componente plural (por el reconocimiento de la estructura societal) e inclusivo (acorde al principio de igualdad y no discriminación), cuyo objetivo es precisamente asegurar la vigencia del pluralismo como elemento fundante del Estado y también con la finalidad de garantizar a través de la interpretación constitucional, el modelo de constitucionalismo fuerte basado en la justicia e igualdad.

\section{ESTRUCTURA DEL MODELO PLURAL DE CONTROL DE CONSTITUCIONALIDAD}

De acuerdo a lo expuesto, es importante precisar que este modelo plural de control de constitucionalidad, se encuentra estructurado en su base por las autoridades jurisdiccionales, administrativas y autoridades de los pueblos indígenas, originarios campesinos, quienes en el ejercicio de sus roles jurisdiccionales, funciones administrativas o funciones enmarcadas en el ámbito de la justicia indígena, originaria y campesina, de acuerdo al principio de aplicación directa de la constitución, y considerando que en sus roles deben utilizar el criterio de interpretación «desde y conforme a la constitución», son los primeros garantes y contralores del respeto a los derechos fundamentales.

En este marco, y considerando las características del sistema de control concentrado de constitucionalidad, cabe hacer notar que en una instancia o nivel intermedio de este sistema, se encuentran los jueces y tribunales de garantías, encargados de conocer las acciones de defensa (acciones tutelares), quienes asumen el control intermedio de constitucionalidad, no como jueces o tribunales ordinarios, sino como «jueces y tribunales de garantías constitucionales», especializados en materia de protección de derechos fundamentales.

Asimismo, en el tercer nivel del control de constitucionalidad, se encuentra el Tribunal Constitucional Plurinacional, como máximo guardián y supremo intérprete de la Constitución, así como pleno garante superior de los derechos fundamentales y garantías constitucionales establecidos por la Constitución.

Por lo expuesto — siguiendo el criterio María Elena Attard-, esta esquematización tripartita del control de constitucionalidad, y el elemento del pluralismo como eje rector no solo de su composición sino también de su rol interpretativo y en particular la inclusión del primer nivel (es decir de las autoridades jurisdiccionales, administrativas y de los pueblos indígenas, originarios y campesinos), con un rol de interpretación constitucional que constituye un cambio trascendental en el sistema jurídico iuspositivista, implican un eje de cambio en las características de los tres modelos jurisdiccionales de control de constitucionalidad conocidos en la doctrina (es decir, el difuso, el 
concentrado y el mixto), y viene a configurar el modelo plural de control de constitucionalidad como un sistema jurisdiccional sui generis, que no es difuso ni tampoco exclusivamente concentrado, puesto que como ha sido explicado, en el primer nivel los jueces y también las autoridades administrativas interpretan la legalidad ordinaria a la luz del bloque de constitucionalidad, en virtud al principio de aplicación directa de la constitución (postulado propio de este modelo constitucional de justicia e igualdad), aspecto que hace que este control sea un sistema combinado con sólidas bases pluralistas (Attard Bellido, 2012: 95-122).

\section{CONFIGURACIÓN NORMATIVA DEL ÓRGANO DE CONTROL}

El sistema jurisdiccional plural de control de constitucionalidad se caracteriza por contener elementos del sistema concentrado de control de constitucionalidad, pero además se inspira en los postulados del pluralismo, la interculturalidad y la descolonización como factores de definición del modelo de Estado. En ese marco, y de acuerdo a lo señalado precedentemente, haciendo una radiografía del sistema se puede señalar que el mismo está diseñado, en un análisis vertical, por tres compartimentos específicos: a) la base del sistema está compuesta por las autoridades jurisdiccionales, las autoridades administrativas, las autoridades de las naciones y pueblos indígenas originarios campesinos y los particulares, quienes son los primeros garantes del bloque de constitucionalidad y de los derechos fundamentales; b) el compartimento intermedio que comprende a los jueces y tribunales de garantías constitucionales que conocen y resuelven las acciones tutelares, y c) el compartimento superior que alberga al último y máximo garante del bloque de constitucionalidad y de los derechos fundamentales: el Tribunal Constitucional Plurinacional.

En efecto, el Tribunal Constitucional Plurinacional se encuentra en la cúspide del sistema jurisdiccional plural de control de constitucionalidad, y se configura como el último y máximo garante tanto del bloque de constitucionalidad como de los derechos fundamentales. Sus roles y diseño, deben consolidar una materialización no solamente de la Constitución como texto escrito, sino esencialmente de los valores plurales supremos para consolidar así el vivir bien; pero además, con base en los antecedentes y presupuestos de la refundación del Estado, una de sus tareas consiste en asegurar los derechos colectivos de las naciones y pueblos indígena originario campesinos, materializando así el corpus iure de derechos de los pueblos indígenas descritos y contextualizados a los ideales y procesos de restitución, igualación y reconstitución, todo en el marco de una convivencia armónica y equilibrada al interior de las naciones y pueblos indígena originario campesinos, entre estos y en relación a toda la sociedad en su conjunto. 
Es importante que este diseño sea analizado con base en un elemento esencial: su composición plural, para asegurar así una interpretación que consagre la interculturalidad plural que, en términos de descolonización, se plasmen procesos constitucionales interculturales para una real materialización del bloque de constitucionalidad.

En la normativa, el art. 196 de la Constitución de 2009, crea el Tribunal Constitucional Plurinacional, con el rol descrito en su numeral primero, por lo que de acuerdo al mandato emanado de la función constituyente, esta instancia vela por la supremacía de la Constitución, ejerce el control de constitucionalidad y precautela el respeto y la vigencia de los derechos y garantías constitucionales. El art. 197 de la Constitución disciplina la organización del Tribunal Constitucional Plurinacional, estableciendo en el primer parágrafo que los magistrados y magistradas del Tribunal Constitucional serán electos con criterios de plurinacionalidad, con representación del sistema ordinario y del sistema indígena originario campesino. Además, el art. 198 de la Constitución, señala que las magistradas y magistrados del Tribunal Constitucional Plurinacional, se elegirán mediante sufragio universal.

Asimismo, es necesario señalar que de acuerdo al art. 199 del texto constitucional, como puntuación adicional para la calificación de méritos de los aspirantes a magistrados y magistradas, se tomará en cuenta el haber ejercido la calidad de autoridad originaria bajo su sistema de justicia. Además, el numeral segundo del referido art., establece que los candidatos podrán ser propuestos por organizaciones de la sociedad civil y naciones y pueblos indígena originario campesinos.

Por su parte, la Ley del Tribunal Constitucional Plurinacional establece la organización del máximo contralor de constitucionalidad en el Estado plurinacional de Bolivia, señalando en el numeral primero de su art. 13 que esta instancia está conformada por siete magistradas y magistrados titulares y siete magistradas y magistrados suplentes. Por su parte, el segundo numeral de la indicada disposición señala que al menos dos magistradas y magistrados provendrán del sistema indígena originario campesino, por autoidentificación personal. Finalmente, debe señalarse que el parágrafo segundo del art. $17 \mathrm{de}$ esta ley, señala que para la calificación de méritos, se tomará en cuenta el haber ejercido la calidad de autoridad originaria bajo su sistema de justicia.

Ahora bien, la referencia normativa antes citada es importante toda vez que la real materialización del bloque de constitucionalidad, en el marco de la visión del modelo de Estado boliviano, encontrará razón de ser en un aspecto esencial: la composición plural, es decir, que los magistrados y magistradas del Tribunal Constitucional Plurinacional no solamente deben tener una visión de la justicia construida desde Occidente, sino también de aquella que emana de las normas y procedimientos ancestrales de las naciones y pueblos indígena 
originario campesino, para que a través de una interpretación intercultural de las problemáticas a ser conocidas opere el principio de complementariedad a través de una interculturalidad plural que irradiará todo el ordenamiento jurídico en el Estado plurinacional de Bolivia.

De acuerdo a lo expuesto, se pueden desprender algunas disfunciones sistémicas (Attard Bellido, 2014: 41-44):

a) del contenido de las disposiciones antes señaladas, se establece que de siete magistradas y magistrados electos que forman parte del Tribunal Constitucional, solamente dos devienen de la jurisdicción indígena originaria campesina, aspecto que no es proporcional para una real materialización del bloque de constitucionalidad, aspecto que incidirá en las pautas interculturales de interpretación, ya que la visión de justicia occidental prevalecerá en las decisiones emanadas de esta instancia. Además, dicha desproporcionalidad incidirá en los procedimientos constitucionales interculturales que deben ser establecidos a la luz del nuevo modelo constitucional y en el marco del pluralismo, la descolonización y la interculturalidad. Prevalecerá una visión formalista y ritualista de la justicia, contraria a la visión del acceso a la justicia en el marco de los parámetros del vivir bien y que, incluso, podría ser contraria al proceso de igualación formulado en esta visión del constitucionalismo, ya que los ritualismos extremos pueden incidir en el acceso a la justicia constitucional de pueblos y naciones indígena originario campesinos.

b) Para las y los magistrados que devengan de la jurisdicción indígena originario campesina, se exige el criterio de autoidentificación personal, tal como establece el art. 13.2 de la Ley del Tribunal Constitucional Plurinacional. Este criterio no aseguraría una real identificación y conocimiento de prácticas de justicia distintas y diferentes a las de la justicia occidental, aspecto que constituye un óbice normativo para una real materialización de una interculturalidad plural en la justicia constitucional y en el sistema jurídico normativo, además de obstaculizar el desarrollo de pautas interculturales de interpretación y procedimientos constitucionales acordes con el nuevo modelo constitucional.

c) Además, la necesidad de una composición plural para asegurar una real materialización del bloque de constitucionalidad imperante, debe ser analizada desde los procedimientos constitucionales y roles encomendados por la función constituyente al Tribunal Constitucional Plurinacional, a cuyo efecto, será menester sistematizar los ámbitos de ejercicio de las atribuciones asignadas a esta instancia, lo cual se resume a continuación. 


\section{LAS DIMENSIONES DEL CONTROL DE CONSTITUCIONALIDAD EN BOLIVIA}

De acuerdo a su configuración constitucional, el Tribunal Constitucional Plurinacional ha sido instituido como el «máximo guardián y supremo intérprete de la Constitución ${ }^{10}$, con la cualidad adicional de defensor de los derechos fundamentales y, por lo mismo, su función principal es la de ejercer en forma exclusiva el control de constitucionalidad con alcance nacional, garantizando la primacía de la Ley Fundamental del Estado, la plena validez del orden constitucional y democrático, así como el respeto y vigencia plena de los derechos fundamentales y garantías constitucionales de las personas.

Precisamente, para el cumplimiento eficaz de esas funciones, el art. 202 de la Constitución Política del Estado, concordante con el art. 12 de la Ley del TCP, enumeran las competencias específicas atribuidas al Tribunal Constitucional Plurinacional, para que este órgano desarrolle su labor jurisdiccional especializada, en una triple dimensión: el control normativo de constitucionalidad ${ }^{11}$; el control sobre el ejercicio del poder político, y el control tutelar de los derechos fundamentales.

10 El Tribunal Constitucional de Bolivia, se constituye en el defensor de la Constitución y del régimen democrático, y se encarga de la protección efectiva e idónea de los derechos fundamentales de las personas; por ello es el máximo guardián y último intérprete de la Constitución, así se infiere de las normas previstas por la Ley Fundamental. "Es el máximo guardián de la Constitución, porque el constituyente le ha encomendado la labor de resguardar la supremacía de la Constitución frente al ordenamiento jurídico ordinario, desarrollando el control especializado y concentrado de la constitucionalidad de las disposiciones legales, emitiendo sentencias con efecto general o erga omnes, anulando la disposición legal incompatible con la Constitución y expulsándola del ordenamiento jurídico del Estado. Dada la naturaleza jurídica de la función que desempeña, es el supremo intérprete de la Constitución, lo cual no significa que el resto de los órganos del poder público en general, los jueces y tribunales en particular, estén impedidos de realizar la interpretación de la Constitución para resolver el caso concreto sometido a su conocimiento; lo que sucede es que, si bien todas las autoridades y funcionarios públicos interpretan la Constitución, quien cierra el proceso realizando una interpretación que vincula a todos los órganos del poder público, autoridades y particulares es el Tribunal Constitucional, por ello se convierte en el último intérprete de la Constitución [...]» (Rivera Santivañez, 2007: 58-59).

11 En cuanto a los alcances del control de constitucionalidad que ejerce el Tribunal Constitucional a través de los recursos (ahora denominados «acciones») de inconstitucionalidad, por cualquiera de las dos vías reconocidas — abstracta o concreta—, dicha labor abarca los siguientes ámbitos: «[...] a) la verificación de la compatibilidad o incompatibilidad de las disposiciones legales impugnadas con las normas de la Constitución Polí- 


\subsection{Control normativo de constitucionalidad de las disposiciones legales}

De acuerdo con las atribuciones que le confieren la Constitución y la Ley 27, el TCP ejerce un control sobre la constitucionalidad de todas las disposiciones legales, sean estas leyes, estatutos autonómicos, cartas orgánicas, decretos y todo género de resoluciones no judiciales, declarando su inconstitucionalidad con carácter general o erga omnes y el efecto derogatorio o abrogatorio conforme corresponda en cada caso. A este efecto, el ordenamiento jurídico establece dos modalidades (en forma previa y posterior) de control de la normatividad:

a) El control normativo previo. Este control se ejerce antes de la aprobación de la respectiva disposición legal, en todos aquellos casos en los que exista una duda fundada sobre su constitucionalidad. Para el efecto, la Ley del TCP ha previsto las siguientes acciones:

1) las consultas de la presidenta o del presidente del Estado plurinacional, de la presidenta o presidente de la Asamblea Legislativa Plurinacional, de la presidenta o presidente del Tribunal Supremo de Justicia o del Tribunal Agroambiental, sobre la constitucionalidad de proyectos de ley (atribución 8. ${ }^{\mathrm{a}}$, del art. 12 de la Ley del TCP);

2) el control previo de constitucionalidad en la ratificación de los tratados internacionales (atribución 9.a);

3) la consulta sobre la constitucionalidad del procedimiento de reforma parcial de la Constitución (atribución 10.a);

tica del Estado, lo que incluye el sistema de valores supremos, principios fundamentales, así como los derechos fundamentales consagrados en dicha Ley Fundamental; b) la interpretación de las normas constitucionales así como de la disposición legal sometida al control desde y conforme a la Constitución Política del Estado; c) el desarrollo de un juicio relacional para determinar si una norma legal es o no conforme con las normas constitucionales; determinando previamente el significado de la norma legal por vía de interpretación, y d) la determinación de mantener las normas de la disposición legal sometida al control. De lo referido se concluye que el control de constitucionalidad no alcanza a la valoración de los fines, los propósitos, la conveniencia o beneficios que pudiese generar la disposición legal sometida a control; lo que significa que el Tribunal Constitucional, como órgano encargado del control de constitucionalidad, no tiene a su cargo la evaluación de si son convenientes, oportunos o benéficos los propósitos buscados por las normas impugnadas, su labor se concentra en el control objetivo de constitucionalidad de las disposiciones legales impugnadas» (Cfr. Sentencia Constitucional No 0051/2005, de 18 de agosto; entendimiento reiterado posteriormente por la Sentencia Constitucional No0048/2010, de fecha 6 de diciembre de 2010). 
4) control previo sobre la constitucionalidad de estatutos autonómicos y cartas orgánicas (atribución 12. ${ }^{a}$, del art. 28 de la Ley del TCP);

5) control previo sobre el texto de las preguntas de la convocatoria a referendo nacional, departamental y municipal (atribución 13. ${ }^{\mathrm{a}}$, del art. 28 de la Ley del TCP);

6) las consultas de las autoridades indígenas originarias campesinas sobre la aplicación de sus normas jurídicas a un caso concreto (atribución 12.a);

b) El control normativo correctivo. Esta forma de control es realizada con posterioridad a la sanción y promulgación de la disposición legal respectiva, en aquellos casos en los que presenten eventualmente una contradicción o incompatibilidad con las normas de la Constitución Política del Estado. El TCP, como órgano jurisdiccional del control de constitucionalidad, lo ejerce al momento de conocer y resolver:

1) las acciones de inconstitucionalidad directas o de carácter abstracto sobre leyes, estatutos autonómicos, cartas orgánicas, decretos y todo género de ordenanzas y resoluciones no judiciales (atribución 1.a , del art. 12 de la Ley del TCP);

2) las acciones de inconstitucionalidad indirectas o de carácter concreto sobre leyes, estatutos autonómicos, cartas orgánicas, decretos y todo género de ordenanzas y resoluciones no judiciales (atribución 2.a);

3) los recursos contra tributos, impuestos, tasas, patentes, derechos o contribuciones, creados, modificados o suprimidos en contravención a lo dispuesto en la Constitución Política del Estado ${ }^{12}$ (atribución 5. a);

\subsection{Control competencial de constitucionalidad}

Es un control que tiene por objeto establecer un equilibrio en el ejercicio del poder político, resolviendo los conflictos constitucionales referidos

12 De acuerdo al Código Procesal Constitucional (arts. 133 al 138), este recurso tiene por objeto garantizar que toda disposición legal que cree, modifique o suprima un tributo, impuesto, tasa, patente, derecho o contribución de cualquier clase o naturaleza, se establezca de acuerdo con la Constitución Política del Estado. Asimismo, la Sentencia Constitucional Plurinacional 0677/2012, de 2 de agosto (Sala Plena), desarrolla entre sus fundamentos jurídicos: 1) naturaleza jurídica y alcances del recurso contra tributos, impuestos, tasas, patentes, derechos o contribuciones especiales; 2) de la legitimación activa y pasiva; 3 ) de los requisitos del recurso, de su contenido y forma; 4) de la procedencia del recurso contra tributos, impuestos, tasas, patentes, derechos o contribuciones especiales. 
al ámbito de las competencias asignadas por la Constitución a los distintos órganos del poder público y a las nuevas entidades territoriales autónomas. El nuevo Tribunal Constitucional Plurinacional deberá cumplir esta función, conociendo y resolviendo:

a) los conflictos de competencia que pudiesen suscitarse entre los órganos del poder público (atribución 3.a , del art. 12 de la Ley del TCP);

b) los conflictos de competencia entre el Gobierno plurinacional (central), las entidades territoriales autónomas y descentralizadas, y de estas entre sí (atribución 4.a);

c) los conflictos de competencia entre la jurisdicción indígena originario campesina y las jurisdicciones ordinaria y agroambiental (atribución 11.a);

d) los recursos directos de nulidad, que proceden contra todo acto o resolución de autoridad pública que usurpe funciones que no le competen, así como contra los actos de la autoridad pública que ejerza jurisdicción o potestad que no emane de la Ley (atribución 13. ${ }^{\mathrm{a}}$, del art. 12 de la Ley del TCP).

\subsection{Control tutelar sobre la vigencia de los derechos fundamentales}

Este control tiene la finalidad de resguardar y garantizar el pleno ejercicio de los derechos fundamentales y garantías constitucionales de las personas, que operan como límites naturales al ejercicio del poder público del Estado. De acuerdo a lo establecido en la atribución $7 .^{\text {a. }}$, del art. 12 de la Ley 27, el Tribunal Constitucional Plurinacional debe ejercer este control a través de la revisión de las resoluciones emitidas a la conclusión de los procesos constitucionales emergentes de las siguientes acciones de defensa:

a) acción de libertad, que extiende su ámbito de protección hacia toda persona que considere que su vida está en peligro, que es ilegalmente perseguida, o que es indebidamente procesada o privada de su libertad personal. Vale decir que en el nuevo sistema constitucional boliviano se han ampliado los alcances de esta acción tutelar, con la finalidad de dar una efectiva protección no solo a quienes se encuentran ilegalmente privados de libertad, sino también a quienes consideren que su libertad física o personal y su propia vida estén amenazadas (Vargas Lima, 2014: 249-288).

b) Acción de amparo constitucional, que extiende su ámbito de procedencia contra actos u omisiones ilegales o indebidas de los servidores públicos, o de personas individuales o colectivas, que restrinjan, supriman o amenacen restringir o suprimir los derechos reconocidos por la Constitución y las leyes. Vale decir que se trata de una acción extraordinaria que tiene 
por objeto la protección inmediata de los derechos fundamentales de las personas, siempre que no exista otro medio o recurso legal para su defensa, a cuyo efecto esta acción tutelar se rige esencialmente por los principios de subsidiariedad e inmediatez, lo que implica la necesidad de otorgar una protección inmediata y eficaz a los derechos fundamentales que en su momento resultaren lesionados (Arias López, 2011: 37-55) ${ }^{13}$.

c) Acción de protección de privacidad, que se activa en favor de toda persona individual o colectiva, que crea estar indebida o ilegalmente impedida de conocer, objetar u obtener la eliminación o rectificación de los datos registrados por cualquier medio físico, electrónico, magnético o informático, en archivos o bancos de datos públicos o privados, o que afecten a sus derechos fundamentales a la intimidad y privacidad personal o familiar, o a su propia imagen, honra y reputación ${ }^{14}$.

d) Acción de cumplimiento, que procede en caso de incumplimiento de disposiciones constitucionales o de la ley, por parte de servidores públicos, con el objeto de garantizar la ejecución de la norma omitida, a cuyo efecto dicha acción es susceptible de interponerse por la persona individual o colectiva afectada, o por otra a su nombre con poder suficiente, ante el juez o tribunal competente, debiendo tramitarse de acuerdo a las mismas reglas de procedimiento previstas para la acción de amparo constitucional (Arias Lopez, 2013: 477-508) ${ }^{15}$.

13 Una argumentación jurídico-constitucional, que desarrolla temáticas referidas a: i) los alcances del control tutelar de constitucionalidad para el resguardo de los derechos fundamentales; ii) las fases procesales de la acción de amparo constitucional; iii) la interpretación desde y conforme a la Constitución Política del Estado, de los arts. 33 y 53 del Código Procesal Constitucional: análisis de los requisitos de forma y causales de improcedencia reglada; iv) la duda razonable para la aplicación del principio pro-actione en etapa de admisibilidad, y v) la apelación y la compulsa como mecanismos idóneos para la defensa intraprocesal de derechos. Puede consultarse en la Sentencia Constitucional Plurinacional 0030/2013, de fecha 4 de enero de 2013.

14 Algunos fundamentos jurídicos sobre la naturaleza jurídica de la acción de protección de privacidad (antes denominado «recurso de hábeas data»), los derechos a la intimidad y privacidad como base de la protección de datos personales, los alcances de esta acción tutelar, sus presupuestos indispensables de procedencia, la legitimación activa y pasiva, así como las reglas de procedimiento para su tramitación, pueden verse ampliamente detalladas en la Sentencia Constitucional 1738/2010-R, de fecha 25 de octubre de 2010.

15 El entendimiento jurisprudencial sobre la naturaleza jurídica de la acción de cumplimiento, así como su ámbito de protección, puede consultarse en la Sentencia Constitucional Plurinacional 0890/2013-L, de fecha 16 de agosto de 2013. 
e) Acción popular, que procede contra todo acto u omisión de las autoridades públicas o de personas individuales o colectivas que «violen» [sic, léase «vulneren»] o amenacen con "violar» [sic, léase «vulnerar»] derechos e intereses colectivos, relacionados con el patrimonio, el espacio, la seguridad y salubridad pública, el medio ambiente y otros de similar naturaleza reconocidos por la misma Constitución ${ }^{16}$.

f) Los recursos contra las resoluciones del Órgano Legislativo, cuando sus resoluciones afecten a uno o más derechos, cualesquiera sean las personas afectadas (atribución 6.a ${ }^{17}$.

De acuerdo a lo expuesto, y a fin de comprender los alcances de la sistematización de estos roles principales que debe cumplir el Tribunal Constitucional Plurinacional, debe prestarse atención a los siguientes aspectos (Attard Bellido, 2014: 46):

16 Un entendimiento jurisprudencial sobre los derechos e intereses colectivos protegidos a través de la acción popular, que conforme señala el art. 135 de la CPE, se encuentran relacionados con el patrimonio, el espacio, la seguridad y salubridad pública, el medio ambiente y otros de similar naturaleza reconocidos por la Ley Fundamental, puede encontrarse en la Sentencia Constitucional Plurinacional 0176/2012, de fecha 14 de mayo de 2012, misma que desarrolla también el alcance del derecho al agua como derecho fundamental y fundamentalísimo en la Constitución Política del Estado y el bloque de constitucionalidad, así como sus vías idóneas de protección. Cabe tener presente también, que la jurisprudencia constitucional ha identificado los derechos colectivos, unas veces como derechos difusos (así las SSCC 1018/2011-R, 1974/2011-R, 1982/2011-R, 1970/2011-R, 1973/2011-R y 1979/2011-R, entre otras) o como derechos de los pueblos (así la SC 1008/2004R). Por otro lado, un análisis de las disposiciones referidas a la admisión de la acción popular, en cuanto a sus requisitos de forma y de contenido, puede consultarse en la Sentencia Constitucional Plurinacional 0462/2012, de fecha 4 de julio de 2012. Finalmente, las temáticas referidas a la legitimación extraordinaria como presupuesto procesal de la acción popular, su carácter subsidiario y la inexistencia de plazo de caducidad, así como el derecho difuso al medio ambiente, pueden consultarse en la Sentencia Constitucional Plurinacional 1082/2013-L, de fecha 30 de agosto de 2013.

17 El Tribunal Constitucional Plurinacional ha establecido que el recurso contra resoluciones del Órgano Legislativo Plurinacional, de acuerdo a su concepto y naturaleza jurídica, «es un proceso constitucional de naturaleza tutelar que tiene por objeto reponer los derechos y garantías constitucionales de la persona, en aquellos casos en los que hubiesen restringido o suprimido, al emitir una resolución legislativa»; a cuyo efecto, ha analizado la naturaleza jurídica de este recurso en la Sentencia Constitucional Plurinacional 1572/2014, de fecha 11 de agosto de 2014 . 
a) el control previo de constitucionalidad es conocido y resuelto por el Pleno del Tribunal Constitucional Plurinacional, ámbito del cual emanan las declaraciones constitucionales. La disfunción de este eje de ejercicio de control de constitucionalidad es la desproporcionalidad que existe entre magistradas y magistrados que devienen de la justicia ordinaria y de la jurisdicción indígena originaria campesina, cuatro contra dos (autoidentificados) y que incide en eventuales retrocesos en temas de interpretación intercultural y procedimientos constitucionales interculturales.

b) El segundo procedimiento de control previo, que es una innovación del modelo constitucional boliviano, es decir la consulta que realizan las autoridades de las naciones y pueblos indígena originario campesinos ante el Tribunal Constitucional Plurinacional, es un verdadero canal para la materialización de un «diálogo intercultural». En ese orden, este procedimiento no es conocido ni resuelto por el Pleno del Tribunal Constitucional Plurinacional, sino por la Sala Especializada, compuesta por los dos magistrados que devienen de la jurisdicción indígena originaria campesina. Así configurado, este procedimiento no genera ninguna disfunción orgánica y, por el contrario, armoniza con los postulados del pluralismo, la interculturalidad y la descolonización en el nuevo modelo de Estado.

c) Los procedimientos inmersos tanto en control normativo como en control competencial de constitucionalidad, son conocidos por el Pleno del Tribunal Constitucional Plurinacional, por cuanto en este ámbito, debe realizarse la misma crítica plasmada en el anterior inciso i).

d) Finalmente, el control tutelar de constitucionalidad, a través del cual, en revisión se conocen y resuelven las acciones de libertad, amparo constitucional, protección de privacidad, de cumplimiento y popular, no es resuelta por el Pleno del Tribunal Constitucional, sino por las tres salas existentes, y de esas tres salas solamente una es la especializada y compuesta por dos magistrados o magistradas que devienen de la justicia indígena originaria campesina, mientras que las otras dos podrían no tener una composición plural (ya que no se exige una composición mixta). Por tanto, las acciones tutelares que devengan de contextos interculturales o que estén vinculadas a pueblos y naciones indígena originario campesinos, podrían en revisión ser resueltas por una sala que no tenga composición plural, aspecto que implicará un análisis desde una visión occidental del derecho y que además podría evitar un avance y desarrollo de pautas interculturales de interpretación y de procedimientos constitucionales interculturales.

Por otro lado, los jueces y tribunales de garantías constitucionales tienen la atribución de conocer en primera instancia las acciones tutelares disciplina- 
das por el régimen constitucional imperante, las cuales, tal como ya se dijo, serán conocidas y resueltas en revisión por cualquiera de las salas del Tribunal Constitucional Plurinacional.

Debe tenerse en cuenta también que en las capitales de los nueve departamentos del Estado plurinacional de Bolivia, las acciones tutelares son conocidas en primera instancia por los vocales de los Tribunales Departamentales de Justicia, divididos en salas, quienes no actúan como tribunales ordinarios sino como tribunales de garantías constitucionales, y sus decisiones son elevadas en revisión, y en el plazo de 24 horas, ante el Tribunal Constitucional Plurinacional.

En las provincias, los jueces ordinarios conocerán y resolverán acciones tutelares, no como jueces ordinarios, sino como jueces constitucionales y sus decisiones serán remitidas al Tribunal Constitucional Plurinacional para su revisión.

Sin embargo, la disfunción sistémica en esta instancia, se da por dos razones especiales (Attard Bellido, 2014: 47):

a) a nivel de jueces y tribunales de garantías, la normativa imperante no reconoce una composición plural. Las acciones tutelares son analizadas en primera instancia con una visión propia de la justicia occidental, aspecto que obstaculiza la aplicación de pautas interculturales de interpretación y la generación de procedimientos constitucionales interculturales, acordes al modelo constitucional vigente.

b) La cultura jurídica en la cual se formaron los jueces y vocales, en la realidad es un obstáculo para la justicia plural constitucional, ya que en esta debe prevalecer la justicia material para la vigencia de derechos fundamentales más allá de ritualismos extremos. Por eso, para evitar una disfunción del sistema, sería apropiado y razonable que en el Estado plurinacional de Bolivia se creen los jueces y tribunales especializados en justicia constitucional plural, con composición mixta.

\section{DESARROLLO JURISPRUDENCIAL DEL MODELO PLURAL DE CONTROL CONSTITUCIONAL}

En este sentido, y acerca del control plural de constitucionalidad diseñado en la Constitución Política del Estado aprobada el año 2009, la jurisprudencia constitucional ha señalado que el reconocimiento transversal de los derechos de las naciones y pueblos indígenas originarios campesinos, abarca también al campo jurídico, pues existe un reconocimiento del pluralismo jurídico igualitario que deriva del reconocimiento constitucional de la igual je- 
rarquía de la jurisdicción indígena originaria campesina con la ordinaria (art. 179.II de la CPE) y del sistema jurídico ordinario con el sistema indígena originario campesino. Entonces, el reconocimiento del pluralismo jurídico igualitario parte de un dato real: la coexistencia dentro del territorio boliviano de diferentes sistemas jurídicos, que tienen sus propias normas, instituciones, autoridades encargadas de administrar justicia y procedimientos para la resolución de sus conflictos, que tiene como base valores, principios y lógicas distintas a la occidental.

La jurisdicción indígena originaria campesina, de acuerdo al art. 179 de la CPE, forma parte del órgano judicial, haciendo efectivo el derecho de las naciones y pueblos indígenas originarios campesinos a que sus instituciones sean parte de la estructura general del Estado (art. 30.II.5 de la CPE) y, en ese ámbito, al gozar de igual jerarquía que la jurisdicción ordinaria, esta no puede revisar las resoluciones pronunciadas por la jurisdicción indígena originara campesina y tampoco esta de aquella; es más, toda autoridad pública o persona debe acatar las decisiones de esta jurisdicción, pudiendo las autoridades solicitar el apoyo de los órganos competentes del Estado (art. 192 de la CPE).

No obstante lo señalado, la jurisdicción indígena originaria campesina, al igual que las demás jurisdicciones, se encuentra limitada por el respeto de los derechos fundamentales a la vida, a la defensa, y demás derechos y garantías establecidas por la Norma Fundamental (art. 190.II de la CPE), debiendo añadirse, además, a los derechos contenidos en los tratados internacionales sobre derechos humanos que forman parte del bloque de constitucionalidad.

Conforme a ello, la Constitución Política del Estado, sobre la base del carácter plurinacional del Estado y el principio de interculturalidad, ha diseñado la justicia constitucional a través del Tribunal Constitucional Plurinacional, como la institución encargada de ejercer el control constitucional sobre la actividad de todas las jurisdicciones y, en general, sobre todos los órganos del poder público a partir del diálogo intercultural que se entable en este órgano, que tiene la representación de los dos sistemas de justicia: el ordinario y el indígena originario campesino.

En ese ámbito, el pluralismo jurídico cobra un nuevo sentido y extensión, pues se reconceptualiza a partir del relacionamiento e influencia permanente de ambos sistemas y a partir de la coordinación y cooperación que debe existir entre las diferentes jurisdicciones que conforman el órgano judicial (ordinaria, indígena originaria campesina, agroambiental y especializadas); así como el principio de unidad de la función judicial (art. 179 de la CPE), por el cual todas las jurisdicciones tienen como denominador común el respeto a los derechos fundamentales, a las garantías constitucionales, y la obediencia a la Constitución Política del Estado, encontrando la unidad en la interpretación final que efectúe el Tribunal Constitucional Plurinacional tanto de los 
derechos y garantías como de las propias normas constitucionales, pues, por el carácter vinculante de sus resoluciones, todos los jueces y autoridades están vinculados a la interpretación efectuada por este órgano.

En ese sentido, debe señalarse que la Constitución boliviana ha diseñado un sistema de control de constitucionalidad plural, pues no solamente se ejerce el control sobre normas formales, sino también sobre las normas de las naciones y pueblos indígena originario campesinos, además de conocer los conflictos de competencias entre las diferentes jurisdicciones y de revisar las resoluciones pronunciadas por la jurisdicción indígena originaria campesina cuando se considere que estas normas son lesivas a los derechos fundamentales y garantías constitucionales. Estas facultades fueron introducidas en la actual Constitución Política del Estado, en mérito al reconocimiento expreso a los derechos de los pueblos indígenas originario campesinos, a la igualdad jerárquica de sistemas jurídicos y jurisdicciones; pero además debe considerarse que la Ley Fundamental fue el resultado de un proceso dialógico en el que intervinieron los diferentes sectores de la población boliviana y, claro está, también las naciones y pueblos indígenas originarios campesinos, que tuvieron un rol protagónico para la consolidación del Estado plurinacional.

Conforme a ello, el Tribunal Constitucional Plurinacional ejerce el control de constitucionalidad de manera plural en tres dimensiones:

a) Control del respeto a los derechos fundamentales y garantías constitucionales o ámbito tutelar: a través de este se verifica si las autoridades, funcionarios públicos o particulares, amenazaron con lesionar o lesionaron los derechos fundamentales y garantías constitucionales. Este control comprende a las acciones de defensa: de libertad, de amparo constitucional, de protección a la privacidad, de cumplimiento y popular. También se encuentra dentro de este ámbito de control el recurso contra resoluciones de la Asamblea Legislativa plurinacional, que afecten a uno o más derechos; sin embargo, en este caso el recurso se presenta directamente ante el Tribunal Constitucional Plurinacional.

b) Control de competencias: dentro de este ámbito de protección, el Tribunal Constitucional Plurinacional conocerá: i) los conflictos de competencias y atribuciones entre órganos del poder público; ii) los conflictos de competencias entre el Gobierno plurinacional, las entidades territoriales autónomas y descentralizadas y entre estas; c) el recurso directo de nulidad, y d) los conflictos de competencia entre la jurisdicción indígena originaria campesina y la jurisdicción ordinaria y agroambiental.

c) Control normativo de constitucionalidad: por el cual se verifican las condiciones de validez formal y material de las normas jurídicas con las disposiciones constitucionales y de las normas que conforman el bloque 
de constitucionalidad. El control normativo de constitucionalidad es ejercido a través de diferentes acciones, siendo una de ellas la acción de inconstitucionalidad, que puede asumir la forma abstracta o concreta (Cfr. Sentencia Constitucional Plurinacional 0300/2012, de fecha 18 de junio de 2012).

Cabe agregar, por otro lado, que las Sentencias Constitucionales Plurinacionales $1227 / 2012$ y 2143/2012, entre otras, establecieron con claridad que el Estado plurinacional de Bolivia adoptó a partir de la aprobación de la Constitución Política del Estado del año 2009, un sistema jurisdiccional plural y concentrado de control de constitucionalidad.

En efecto, de manera detallada, la Sentencia Constitucional Plurinacional 2143/2012, de 8 de noviembre, para establecer el sistema de control de constitucionalidad imperante, desarrolló las características tanto del sistema de control político de constitucionalidad como del sistema jurisdiccional de control de constitucionalidad. El citado entendimiento señaló que, «a partir de la reforma constitucional de 1994, Bolivia adoptó un sistema preeminentemente concentrado de control de constitucionalidad en manos del Tribunal Constitucional», el cual ejerció roles preventivos y reparadores de control de constitucionalidad, cuyo ejercicio fue desarrollado orgánica y competencialmente por la Ley 1836 de 1 de abril de 1998, denominada «Ley del Tribunal Constitucional».

Asimismo, la Sentencia Constitucional Plurinacional antes aludida, precisó también que luego de la «reforma constitucional de 2009» [sic], el Estado plurinacional de Bolivia adopta un sistema jurisdiccional concentrado y plural de control de constitucionalidad, en manos del Tribunal Constitucional Plurinacional, instancia que ejerce sus roles propios del control plural de constitucionalidad a partir de la posesión de sus magistradas y magistrados con composición plural y electos por sufragio popular.

En el marco de lo señalado, se establece que el control plural de constitucionalidad, cuya máxima instancia está encomendada al Tribunal Constitucional Plurinacional, ejerce todos los roles jurisprudenciales disciplinados en la parte orgánica de la Constitución, de manera específica en el art. 202.1 de la CPE, concordante con el art. 196.I de la Norma Suprema; por tanto, al existir una instancia imparcial, independiente y especializada en justicia plural constitucionalidad, se colige que en el Estado plurinacional de Bolivia, impera un sistema jurisdiccional plural y concentrado de control de constitucionalidad, instancia a la cual la función constituyente encomendó tanto el cuidado del bloque de constitucionalidad como el resguardo a los derechos fundamentales, en su faceta de derechos individuales o derechos con incidencia colectiva 
(Cfr. Sentencia Constitucional Plurinacional 0778/2014, de fecha 21 de abril de 2014).

\section{CONCLUSIONES}

Como se ha podido apreciar a lo largo de este estudio, una breve revisión de las reformas y modificaciones del sistema constitucional permite afirmar que durante la evolución y desarrollo histórico del sistema constitucional boliviano, se han adoptado progresivamente los diferentes modelos de control que se conocen en la doctrina del derecho procesal constitucional.

Así, en un primer momento de su vida republicana (1826-1861), bajo la influencia del liberalismo francés, configuró un modelo político de control de constitucionalidad a través de un Consejo de Estado; en una segunda etapa (1861-1994), adoptó el modelo americano, es decir, el sistema jurisdiccional difuso de control de constitucionalidad a través de la Corte Suprema de Justicia; en la tercera etapa (1994-2009), adoptó el sistema jurisdiccional concentrado de control de constitucionalidad con la atribución exclusiva del control a un órgano especializado proveniente del modelo europeo, que fue denominado Tribunal Constitucional y, finalmente, en la cuarta etapa (2009 hacia adelante), se ha configurado constitucionalmente un sistema predominantemente concentrado y plural de constitucionalidad en Bolivia, según el entendimiento desarrollado por la jurisprudencia reciente del Tribunal Constitucional Plurinacional, a partir de la interpretación de las normas establecidas por la Constitución aprobada el año 2009.

Entonces, teniendo en cuenta que como efecto de la aprobación de la Constitución Política del Estado Plurinacional en el año 2009, se ha refundado el Estado boliviano bajo un modelo constitucional basado en el pluralismo, la interculturalidad y la descolonización, ello marca una nueva etapa del constitucionalismo boliviano, con rasgos y particularidades específicas que lo caracterizan y diferencian de los demás modelos constitucionales, especialmente de aquellos con raíces en el constitucionalismo europeo.

Es así que se ha instituido un Tribunal Constitucional de carácter Plurinacional, configurándose un sistema plural de control de constitucionalidad, con bases notorias en el sistema jurisdiccional concentrado de control constitucional, que estuvo vigente hasta antes de la aprobación del nuevo texto constitucional; empero, esta vez, se agrega un componente plural (por el reconocimiento de la estructura societal diversa) e inclusivo (de acuerdo al principio de igualdad y no discriminación), cuyo objetivo es asegurar la vigencia del pluralismo como elemento fundante del Estado, para garantizar a través de la 
interpretación constitucional, el modelo de constitucionalismo fuerte basado en la justicia e igualdad.

En este sentido, la jurisprudencia constitucional ha emitido varios pronunciamientos señalando expresamente que la Constitución boliviana ha diseñado un sistema de control plural de constitucionalidad, pues no solamente se ejerce el control sobre normas formales, sino también sobre las normas de las naciones y pueblos indígenas originarios campesinos, además de conocer los conflictos de competencias entre las diferentes jurisdicciones y de revisar las resoluciones pronunciadas por la jurisdicción indígena originaria campesina cuando se considere que estas normas son lesivas a los derechos fundamentales y garantías constitucionales.

Estas facultades fueron introducidas en la actual Constitución Política del Estado, en mérito al reconocimiento expreso a los derechos de los pueblos indígenas originarios campesinos y a la igualdad jerárquica de sistemas jurídicos y jurisdicciones; ello, pone de manifiesto que la Ley Fundamental aprobada en la Asamblea Constituyente (2007) y refrendada por el pueblo boliviano (2009), a pesar de las diferentes vicisitudes que tuvo que atravesar, fue el resultado de un proceso dialógico en el que intervinieron diferentes sectores de la población boliviana, incluyendo también a las naciones y pueblos indígena originarios campesinos, que tuvieron un rol protagónico para la implementación del actual Estado plurinacional en construcción.

Evidentemente, es amplia la gama de atribuciones previstas por la Constitución Boliviana (2009) y la Ley 27 del Tribunal Constitucional Plurinacional (2010), para que el máximo órgano de la jurisdicción constitucional en Bolivia asegure la primacía del texto constitucional a través del control de la constitucionalidad, a cuyo efecto se lo ha instituido como máximo guardián y supremo intérprete de la Constitución, con la cualidad especial de defensor de los derechos fundamentales; en consecuencia, esta entidad colegiada desarrolla funciones jurisdiccionales en el ámbito normativo, competencial y tutelar, de acuerdo a la configuración procesal de las acciones de defensa y recursos establecidos por la Constitución, y desarrollados por la Ley N254 que aprueba el Código Procesal Constitucional (2012), ejerciendo así en forma exclusiva el control de constitucionalidad con alcance nacional, garantizando la primacía de la Ley Fundamental del Estado, la plena validez del orden constitucional y democrático, así como el respeto y vigencia plena de los derechos fundamentales y garantías constitucionales en el Estado plurinacional de Bolivia.

Sin embargo, se ha evidenciado también que la configuración normativa, y por ende, la estructura orgánica de este nuevo sistema de control plural de constitucionalidad en el país, adolece de algunos defectos, tornándose insuficiente, dado que existen algunos desfases y disfuncionalidades que afectan su efectividad y su plena vigencia en la práctica judicial en sede constitucional; 
por ello, resulta loable la reciente propuesta impulsada por el propio Tribunal Constitucional Plurinacional, para la creación de «Salas Constitucionales» en cada uno de los tribunales departamentales (en reemplazo de los tribunales de garantías que hasta ahora subsisten), dado que ello indudablemente coadyuvará en el descongestionamiento procesal, fortaleciendo la Administración de Justicia constitucional en Bolivia. No obstante, ello exige a su vez una necesaria revisión de la configuración normativa del órgano encargado del control de constitucionalidad, para precisar sus alcances y atribuciones específicas.

Así también, es importante impulsar la especialización tanto de los jueces y Tribunales de Garantías Constitucionales, como de los magistrados del Tribunal Constitucional Plurinacional en la sustanciación y resolución de los procesos constitucionales que son sometidos a su conocimiento, para que puedan desempeñar sus funciones jurisdiccionales en armonía con los postulados del pluralismo, la interculturalidad y la descolonización, vigentes en nuestro nuevo modelo de Estado, logrando así la aplicación de pautas interculturales específicas de interpretación y la generación de procedimientos constitucionales interculturales, acordes al modelo constitucional vigente.

En definitiva, el desarrollo adecuado y la plena consolidación del modelo de control plural de constitucionalidad en Bolivia, depende de la optimización de las normas establecidas para realizar el control normativo, competencial y tutelar, así como de la especialización y capacitación de los jueces, juezas y Tribunales de Garantías Constitucionales, y de los miembros del propio Tribunal Constitucional Plurinacional, quienes deben desarrollar sus actividades jurisdiccionales en el marco del pluralismo jurídico, la interculturalidad y la descolonización que proclama la Constitución.

\section{BIBLIOGRAFÍA}

Arias López, B. (2011). La acción de amparo constitucional en el «estado de transición constitucional» boliviano. IUS: Revista del Instituto de Ciencias Jurídicas de Puebla, 5 (27), 37-55. Disponible en: http://scielo.unam.mx/pdf/rius/n27/n27a3.pdf.

- (2013). La acción de cumplimiento como acción tutelar. Revista Ius et Praxis, 19 (2), 477-508. Disponible en: http://www.scielo.cl/pdf/iusetp/v19n2/art17.pdf.

Asbun, J. (1999). Control constitucional en Bolivia. Evolución y perspectivas. Revista Constitucional, 3.

Attard Bellido, M. E. (2010). Estándares jurisprudenciales, principios y directrices supra-estatales vinculados a derechos colectivos y difusos a ser aplicados en el Estado plurinacional de Bolivia.

- (2012a). La justiciabilidad de los DESC en el constitucionalismo de la justicia e igualdad asumido por el modelo constitucional del estado plurinacional de Bo- 
livia. Lex social: Revista de los Derechos Sociales, 1, 95-122. Disponible en: http:// www.upo.es/revistas/index.php/lex_social/article/view/271.

- (2012b). La última generación del constitucionalismo: el pluralismo descolonizador intelectual y sus alcances en el Estado plurinacional de Bolivia. Disponible en: http:// www.upo.es/revistas/index.php/lex_social/article/download/283/280.

- (2014). Sistematización de jurisprudencia y esquemas jurisprudenciales de pueblos indígenas en el marco del sistema plural de control de constitucionalidad. La Paz: Fundación Konrad Adenauer, Fundación Construir, Presencia. Disponible en: http:// www.kas.de/bolivien/es/publications/41350/.

Baldivieso Guzmán, R. (2006). Derecho Procesal Constitucional. Tribunal, procedimientos y jurisprudencia en Bolivia. Santa Cruz, Bolivia: Industrias Gráficas Sirena.

Bolívar, S. (1973). Siete documentos esenciales. Caracas, Venezuela: Ediciones de la Presidencia de la República.

Durán Ribera, W. R. (2003) El sistema de control de constitucionalidad vigente en Bolivia. En Tribunal Constitucional de Bolivia. La Justicia Constitucional en Bolivia 1998-2003. Sucre, Bolivia: Grupo Editorial Kipus.

- (2005). Principios, Derechos y Garantías Constitucionales. Santa Cruz, Bolivia: Comunicaciones El País.

Fernández Segado, F. (2002). La Jurisdicción Constitucional en Bolivia. La Ley número 1836 de $1^{\circ}$ de abril de 1998, del Tribunal Constitucional. México D.F.: Instituto de Investigaciones Jurídicas, UNAM.

- (2004). La justicia constitucional ante el siglo XXI: la progresiva convergencia entre los sistemas americano y europeo-kelseniano.México: Instituto de Investigaciones Jurídicas, UNAM. Disponible en: http://biblio.juridicas.unam.mx/libros/libro.ht$\mathrm{m} ? \mathrm{l}=1503$.

- (2012). Estudios de Derecho Constitucional Latinoamericano. Arequipa, Perú: Editorial Adrus.

Galindo de Ugarte, M. (1994). ¿Tribunal Constitucional o Corte Suprema? Una contribución al debate. La Paz: Fundación Milenio, Producciones CIMA.

Galindo Decker, H. (1994). Tribunal Constitucional. La Paz: Editorial Jurídica Zegada.

Lösing, N. (2002). La jurisdiccionalidad constitucional en Latinoamérica. Madrid: Konrad Adenauer Stiftung, Editorial Dykinson.

Nogueira Alcalá, H. (2006). La justicia y los tribunales constitucionales de Indoiberoamérica del Sur en la alborada del Siglo XXI. Cochabamba, Bolivia: Kipus.

Rivera Santiváñez, J. A. (1999). El control de constitucionalidad en Bolivia. Revista del Tribunal Constitucional, 1.

- (2002a). Recurso de inconstitucionalidad en Bolivia. En J. Vega Gómez y E. Corzo Sosa (coords.). Instrumentos de tutela y justicia constitucional. Memoria del VII Congreso Iberoamericano de Derecho Constitucional. México: Instituto de Investigaciones Jurídicas, UNAM.

- (2002b). Reforma Constitucional en Democracia. En Academia Boliviana de Estudios Constitucionales. Análisis de la Reforma a la Constitución Boliviana. Santa Cruz, Bolivia: Editorial El País. 
- (2007). El Tribunal Constitucional defensor de la Constitución. Reflexiones sobre la necesidad de su consolidación y fortalecimiento institucional. Sucre, Bolivia: GTZ-PADEP, Unión Europea, AECI.

- (2008a). El Tribunal Constitucional: una década transitando un sendero con obstáculos. Revista Opiniones y Análisis, 90.

- (2008b). El Tribunal Constitucional: una década transitando un sendero con obstáculos (2009). El Nuevo Sistema Constitucional del Estado Boliviano. En Academia Boliviana de Estudios Constitucionales. Estudios sobre la Constitución aprobada en enero de 2009. Cochabamba, Bolivia: Grupo Editorial Kipus.

- (2008c). El Tribunal Constitucional: una década transitando un sendero con obstáculos (2011). En Jurisdicción Constitucional. Procesos Constitucionales en Bolivia. Tercera ed. actualizada con la Constitución y la Ley 27. Cochabamba, Bolivia: Grupo Editorial Kipus.

Trigo, C. F. (2003). Las constituciones de Bolivia. Prólogo de Manuel Fraga Iribarne. Adiciones y actualizaciones (1961-2002), Jorge Antonio Asbun Rojas. 2a ed. La Paz: Fondo Editorial de la Biblioteca y Archivo Histórico del Honorable Congreso Nacional.

Urcullo Reyes, J. (2003). El control jurisdiccional de revisión judicial o difuso en Bolivia. En Tribunal Constitucional de Bolivia. La Justicia Constitucional en Bolivia 19982003. Sucre, Bolivia: Grupo Editorial Kipus.

Vargas Lima, A. E. (2014). La acción de libertad en la Constitución boliviana. Naturaleza jurídica, oralidad y subsidiariedad de acuerdo a las modulaciones de la jurisprudencia constitucional. Revista Iberoamericana de Derecho Procesal Constitucional, 22.

Virreira Flor, R. (1977). De los procesos y recursos previstos en la Constitución Política del Estado. Corte Suprema de Justicia de la Nación. En 5 Estudios jurídicos (sobre temas de los nuevos Códigos bolivianos, Civil y de Procedimiento Civil). Vol. I. Sucre, Bolivia: Biblioteca Jurídica. 